\title{
Hemispherical photography to estimate biophysical variables of cotton
}

\author{
Ziany N. Brandão ${ }^{1}$ \& João H. Zonta ${ }^{1}$ \\ ${ }^{1}$ Embrapa Algodão/Departamento de Pesquisa e Desenvolvimento. Campina Grande, PB. E-mail: ziany.brandao@embrapa.br; joao-henrique.zonta@embrapa.br \\ (Corresponding author)
}

Key words:

leaf area index

cotton biomass

Plant Canopy Imager CI-110

\begin{abstract}
A B S T R A C T
The Leaf Area Index (LAI) is a key parameter to evaluate the vegetation spectral response, estimating plant nutrition and water requirements. However, in large fields is difficult to obtain accurate data to LAI determination. Therefore, the objective of this study was the estimation of LAI, biomass and yield of irrigated cotton through digital hemispherical photography. The treatments consisted of four nitrogen doses $\left(0,90,180\right.$ and $\left.270 \mathrm{~kg} \mathrm{ha}^{-1}\right)$ and four phosphorus doses $\left(0,120,240\right.$ and $\left.360 \mathrm{~kg} \mathrm{ha}^{-1}\right)$. Digital hemispherical photographs were collected under similar sky brightness conditions at 60 and 75 days after emergence (DAE), performed by the Digital Plant Canopy Imager - CI- $110^{\circ}$ of CID Inc. Biomass and LAI measurements were made on the same dates. LAI was also determined by destructive and non-destructive methods through a leaf area integrator (LI-COR ${ }^{\circledR}$-LI-3100C model), and by measurements based on the midrib length of all leaves, respectively. The results indicate that the hemispherical images were appropriate to estimate the LAI and biomass production of irrigated cotton, while for the estimation of yield, more research is needed to improve the method.
\end{abstract}

\section{Palavras-chave:}

índice de área foliar biomassa do algodoeiro

Plant Canopy Imager CI-110

\section{Estimativa de variáveis biofísicas do algodoeiro por meio de fotografia hemisférica}

\section{R E S U M O}

O Índice de Área Foliar (IAF) é um parâmetro essencial na avaliação da resposta espectral da vegetação e estimativa das necessidades nutricionais e hídricas das culturas, porém é difícil obter sua estimativa de forma rápida e precisa em grandes áreas. O objetivo deste estudo foi a estimativa do IAF, da biomassa aérea e da produtividade do algodoeiro irrigado por meio de fotografia hemisférica digital. O experimento consistiu de uma combinação fatorial de quatro doses de nitrogênio $\left(0,90,180\right.$ e $\left.270 \mathrm{~kg} \mathrm{ha}^{-1}\right)$ e quatro de fósforo $(0,120$ e 240 e 360 $\left.\mathrm{kg} \mathrm{ha}^{-1}\right)$. As fotografias hemisféricas foram obtidas em condições similares de intensidade de brilho no céu aos 60 e 75 dias após a emergência (DAE) utilizando-se o Digital Plant Canopy Imager - CI- $110^{\circledR}$ da CID Inc. O IAF também foi obtido por métodos destrutivos e não-destrutivos com o uso de um integrador de área foliar da LI-COR ${ }^{\circledR}$ modelo LI-3100C e por medições baseadas no comprimento da nervura central de todas as folhas. A análise de imagens hemisféricas obtidas por meio do Digital Plant Canopy Imager CI- $110^{\circ}$ constitui um método adequado para a estimativa do IAF e da biomassa do algodoeiro e para a estimativa da produtividade são necessários mais estudos para aperfeiçoar o método. 


\section{INTRODUCTION}

Leaf area index (LAI) is a biophysical variable that expresses the growth rate of the vegetation showing close relationship with crop yield (MacFarlane et al., 2007). LAI enables the achievement of some canopy structural parameters, such as the aerial biomass as well as the primary productivity from the photosynthetically active surface (Chirici et al., 2007). Therefore, the reliable estimation capacity of this parameter can also contribute to assessing crop yields (MacFarlane et al., 2007; Zarate-Valdez et al., 2012).

Leaf area estimation can be performed by direct or indirect methods. Direct methods are expensive and complex, since the sampling restricts the amount of measurements to be performed. On the other hand, indirect methods provide non-destructive and reliable results, which, in general, are based on the light transmittance measurements through the canopy. Additionally, indirect measurements have the advantage of obtaining a lot of data in a small area, so that the variable being studied can be better assessed.These methods are widely used to estimate the LAI, since they are easy to use and less expensive than conventional methods, which require vegetation destruction.

Among the methods for LAI remote estimation, hemispherical canopy photography, also known as fisheye lens photography, is being applied successfully in commercial plantations. The hemispherical photography is based on the estimated position, size, density and distribution of canopy gaps, which characterize the canopy geometry, through which the solar radiation intercepted is measured. The acquisition of high-definition photos under the canopy is quickly analyzed by proprietary software, taking as a basis algorithms with the zenith angle, the light attenuation and the contrast between plants and sky. The advantages of using hemispherical images, including high-resolution images to LAI estimation are discussed by Jonckheere et al. (2004), Chianucci \& Cutini (2012) and Zhao et al. (2012).

Besides LAI, the hemispherical photographs quickly provide the spatial and temporal variability of light and solar radiation below the canopy and how this influences the structure characterization and changes in plant development or in the environment. For these reasons, this technique is used by authors in the estimation of biophysical parameters such as LAI and biomass of large forested areas (Jonckheere et al., 2005; MacFarlane et al., 2007; Clark \& Murphy, 2011; Woodgate et al., 2015), or for analysis of permanent crops (Simões et al., 2007; Khabba et al., 2009; Espinosa et al., 2010). However, for annual crops, this technique should be still studied and correlated to crop growth and yield.

In order to assess Leaf Area Index data from hemispherical photography $\left(\mathrm{LAI}_{\mathrm{HP}}\right)$, it is important to analyze their relationship with LAI obtained by conventional destructive or not-destructive methods. This work aims to estimate LAI and aerial biomass in cotton with a CI-110 camera CID ${ }^{\circledR}$ (Digital Plant Canopy Imager (CID Inc., Camas, WA, USA)) and compare the results with those obtained from destructive measurements using the LI-3100 Licor', and non-destructive measurements using estimated leaf area through the midrib length of the leaves (Miller et al., 2007; Fideles Filho et al., 2010.).

\section{Material ANd Methods}

The experiment was carried out during the 2010-2011 season, at the Experimental station of EMPARN - Agricultural Research Company of Rio Grande do Norte, located in Apodi town, with central coordinates of 5'37' $19^{\prime \prime}$ S and 37'49' $06^{\prime \prime}$ $\mathrm{W}$, and altitude ranging between 128 and $132 \mathrm{~m}$.

The climate of the region is semiarid and hot tropical with a predominance of the BSw'h' type, according to Köppen's climate classification. Annual precipitation has average of $920 \mathrm{~mm}$, concentrated in summer and fall (late December until May). The soil in the experimental area was classified as eutrophic Cambisol, and the texture is sandy clay, with $49 \%$ of sand, $45 \%$ of clay and $6 \%$ of silt, field capacity (fc $=0.1700 \mathrm{~kg}$ $\left.\mathrm{kg}^{-1}\right)$, wilting point $\left(\mathrm{wp}=0.1133 \mathrm{~kg} \mathrm{~kg}^{-1}\right)$, soil bulk density (bd $\left.=1.20 \mathrm{~kg} \mathrm{dm}^{-3}\right)$, soil particle density $\left(\mathrm{dp}=2.71 \mathrm{~kg} \mathrm{dm}^{-3}\right)$ and total porosity $\left(\mathrm{Po}=0.5558 \mathrm{~m}^{3} \mathrm{~m}^{-3}\right)$. Fertilization was carried out according to the technical recommendations for cotton, based on the analysis of soil fertility. Before the experiment, soil analysis presented in the $0-20 \mathrm{~m}$ layer the following results: $\mathrm{pH}$ in $\mathrm{H}_{2} \mathrm{O}$ (1: 2.5): 5.7; $\mathrm{Ca}^{2+}: 28.0 \mathrm{mmol}_{\mathrm{c}} \mathrm{dm}^{-3} ; \mathrm{Al}^{3+}: 1.5 \mathrm{mmol}_{\mathrm{c}}$ $\mathrm{dm}^{-3}$; H+Al: $17.3 \mathrm{mmol}_{\mathrm{c}} \mathrm{dm}^{-3}$; P (Mehlich 1): $4.4 \mathrm{mg} \mathrm{dm}^{-3} ; \mathrm{K}^{+}$: $4.7 \mathrm{mmol}_{\mathrm{c}} \mathrm{dm}^{-3} ; \mathrm{Mg}^{2+}: 5.5 \mathrm{mmol}_{\mathrm{c}} \mathrm{dm}^{-3} ; \mathrm{Na}^{+}: 0.8 \mathrm{mmol} \mathrm{dm}_{\mathrm{c}}^{-3}$; S: 39.0 mmol $_{\mathrm{c}} \mathrm{dm}^{-3}$; V: 69.0\%; OM: $9.0 \mathrm{~g} \mathrm{~kg}^{-1}$.

In order to obtain a wide range of data, with different leaf area, biomass and cotton yield, the experiment consisted in a factorial combination of four nitrogen doses $(0,90,180$ and $\left.270 \mathrm{~kg} \mathrm{ha}^{-1}\right)$ and four phosphorus doses $(0,120,240$ and 360 $\mathrm{kg} \mathrm{ha}^{-1}$ ) applied in the preceding cultivation of cotton (season 2009-2010). It was adopted a completely randomized design, in a split-plot scheme with four replicates.

Before planting, a ton of gypsum per hectare was applied for soil correction. Fertilization of plants was performed by applying $\mathrm{K}_{2} \mathrm{O}: 40 \mathrm{~kg} \mathrm{ha}^{-1}$ in the potassium chloride form, B: $2.45 \mathrm{~kg} \mathrm{ha}^{-1}$ as boric acid, Ca: $1.78 \mathrm{~kg} \mathrm{ha}^{-1}$; S: $1.43 \mathrm{~kg} \mathrm{ha}^{-1}$; Cu: $0.2 \mathrm{~kg} \mathrm{ha}^{-1}$; Mn: $0.5 \mathrm{~kg} \mathrm{ha}^{-1}$; Mo: $0.025 \mathrm{~kg} \mathrm{ha}^{-1}$ and Zn: $2.25 \mathrm{~kg}$ $\mathrm{ha}^{-1}$ according tothe recommendation of Embrapa obtained in Carvalho et al. (2008). It was used urea for nitrogen fertilizer, with $30 \%$ of the dose applied at sowing and the remaining applied 40 days after emergence (DAE). Phosphate fertilizer was not applied as a way to evaluate the residual effect of this nutrient in the previous crop cultivation.

It was used the cultivar BRS $1878 \mathrm{H}$, sown on September 1, 2010. Before planting, an irrigation was performed in order to increase soil moisture to field capacity until the depth of $0.60 \mathrm{~m}$. After sowing, irrigations were performed twice a week using a conventional sprinkler system with spacing between nozzles of 12 $\mathrm{x} 15 \mathrm{~m}$. Irrigation depths were based on crop evapotranspiration (ETc), obtained by multiplying the reference evapotranspiration (ETo), calculated with the Penman-Montheith method - FAO 56 (Allen et al., 1998), by the crop coefficient (Kc), tabulated and varying depending on the crop phenological stage.

The plots occupied an area of $175.5 \mathrm{~m}^{2}$, where each experimental unit consisted of thirteen $15 \mathrm{~m}$ long rows, spaced at 0.9 and $0.1 \mathrm{~m}$ between plants in the row. Plant growth was 
evaluated after 60 and 75 DAE (stages F3 and C1 according to the scale of Marur \& Ruano (2001)) to obtain plant height, number of leaves and midrib length of all leaves in 10 plants previously selected.

Leaf area of each plant was obtained by three different techniques. The first one was destructive, in which all leaves of the same plant were measured using a leaf area meter (LI-COR'- model LI-3100C). The second and third methods used non-destructive techniques, which measured, before harvesting, the leaf area of the same 10 selected plants per plot. These non-destructive techniques were the hemispherical images with CI- $110^{\circ}$ and the metric method based on the midrib length of all leaves in a single plant. The Eq. 1 shows the leaf area based on midrib length, where $\mathrm{Y}$ is the plant leaf area $\left(\mathrm{cm}^{2}\right.$ plant $\left.{ }^{-1}\right), X$ is the midrib length $(\mathrm{cm})$ and $\mathrm{a}=0.4322$ and $b=2.3032$ are the regression coefficients for cotton plants (Fideles Filho et al., 2010).

$$
\mathrm{Y}=0.4322 \cdot \mathrm{X}^{2.3032}
$$

Digital hemispherical images were acquired from the tops of the selected plants using the Digital Plant Canopy Imager - CI$110^{\circ}$ (CID Inc). The images were obtained at three centimeters from the soil surface to the sky (soil-sky direction) and early in the morning between 7 and $8 \mathrm{~h}$, under partly cloudy sky (Figure 1), with direct and diffuse radiation reaching the ground.

Due to the high brightness of northeastern Brazil, especially in the semiarid region, it was not possible to obtain images in diffuse light conditions (in the dawn and dusk periods or in days with the sky uniformly cloudy) in order to get the maximum possible contrast between the leaves and the sky (Jonckheere et al., 2004). For the evaluation of average error due to light scattering, 3 treatments were chosen and measurements performed in the high luminance hours.

The CI- $110^{\circ}$ has an integrated CCD camera for taking hemispherical images while the proprietary software calculates the photosynthetically active radiation and instantaneous leaf

A.

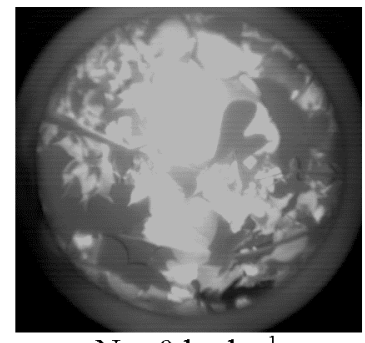

$\mathrm{N}=0 \mathrm{~kg} \mathrm{ha} \mathrm{a}^{-1}$

B.

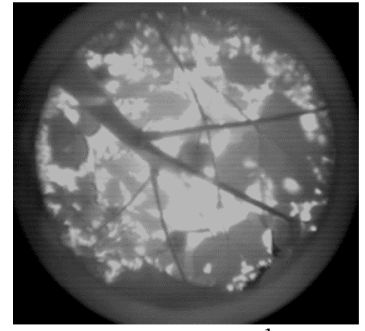

$\mathrm{N}=0 \mathrm{~kg} \mathrm{ha} \mathrm{g}^{-1}$

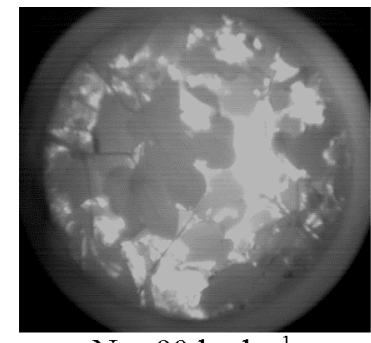

$\mathrm{N}=90 \mathrm{~kg} \mathrm{ha}^{-1}$

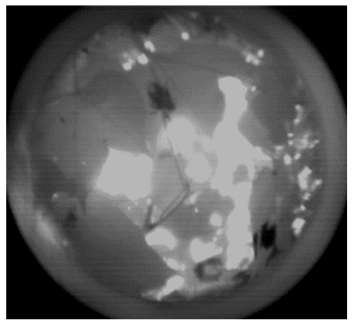

$\mathrm{N}=90 \mathrm{~kg} \mathrm{ha}^{-1}$

area index. The radiation was obtained by two pyranometers connected to an automatic data acquisition system (Datalogger CR 3000 by Campbell Scientific) adjusted with other sensors in the automatic weather station installed in the site of the experiment.The system was programmed to collect data every $5 \mathrm{~s}$ and store averages in $20 \mathrm{~min}$ intervals, with recorded values of 3320 and $3564 \mathrm{~kJ} \mathrm{~m}^{-2}$ at 13:30 h, on 60 and $75 \mathrm{DAE}$, respectively. Figure 1 shows hemispherical images acquired on 60 and 75 DAE for cotton with different $\mathrm{N}$ doses.

The CI- $110^{\circ}$ proprietary software provides LAI automatically for each photo. For the metric method, leaf area index (LAI) $\left(\mathrm{cm}^{2}\right.$ $\mathrm{cm}^{-2}$ ) was determined based on ratio between the total leaf area of each plant and the soil surface under the same plant (Fideles Filho et al., 2010). The same cotton plants that were removed for LAI measurements by the planimeter provided the green and dry biomass. These plants were cut to $3 \mathrm{~cm}$ above the soil surface. The collected plants were washed and separated into root, fruiting structures, stem and leaves, for LAI and fresh weight determination. Thereafter, plants were dried to obtain the dry weight.

Regressions were calculated between the results acquired by hemispherical photography and the destructive and the nondestructive methods. Additionally, the correlation coefficients, mean absolute error (MAE) and the root mean square error (RMSE) were determined. The RMSE is the root mean square error between the prediction and actual data, which indicates the average magnitude of the errors, while MAE measures the average magnitude of the errors in a set of predictions, without considering their direction, that is, it measures accuracy for continuous variables. They are given by the following expressions:

$$
\begin{gathered}
\text { MAE }=\frac{1}{N} \sum_{i=1}^{n}\left|P_{i}-O_{i}\right| \\
\text { RMSE }=\sqrt{\frac{1}{N} \sum_{i=1}^{n}\left(P_{i}-O_{i}\right)^{2}}
\end{gathered}
$$

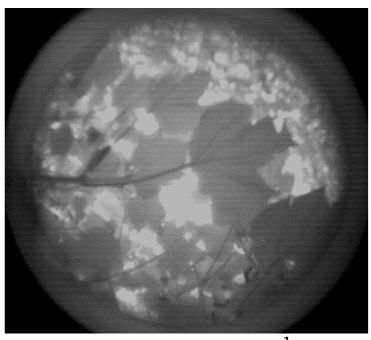

$\mathrm{N}=180 \mathrm{~kg} \mathrm{ha}^{-1}$

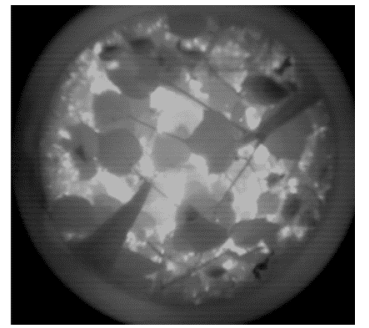

$\mathrm{N}=180 \mathrm{~kg} \mathrm{ha}^{-1}$

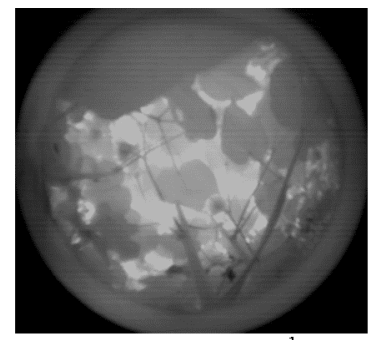

$\mathrm{N}=270 \mathrm{~kg} \mathrm{ha}^{-1}$

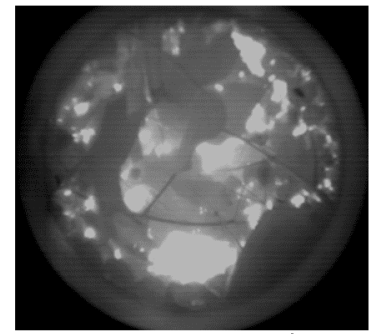

$\mathrm{N}=270 \mathrm{~kg} \mathrm{ha}^{-1}$

Figure 1. Hemispherical images of irrigated cotton for treatments with maximum residual dose of $\mathrm{P}_{2} \mathrm{O}_{5}(360 \mathrm{~kg}$ ha-1) and four nitrogen doses $\left(0,90,180,270 \mathrm{~kg} \mathrm{ha}^{-1}\right)$, to: (A) 60 and (B) 75 days after emergence (DAE) 
where $\mathrm{N}$ is the total number of observation-prediction pairs, $\mathrm{Pi}$ is the $\mathrm{i}$-th prediction and $\mathrm{Oi}$ is the $\mathrm{i}$-th observation.

\section{Results AND Discussion}

The LAI values acquired by hemispherical photography $\left(\mathrm{LAI}_{\mathrm{HP}}\right)$ ranged from 0.85 to 1.79 and from 1.01 to 1.90 at 60 and $75 \mathrm{DAE}$, respectively. At the same dates, LAI measured by LI$3000 \mathrm{C}\left(\mathrm{LAI}_{\text {dest }}\right)$ ranged from 1.14 to 4.22 and from 1.54 to 6.04 .

Hemispherical Photography LAI $\left(\mathrm{LAI}_{\mathrm{HP}}\right)$ underestimates the measured values of LAI $\left(\mathrm{LAI}_{\text {dest }}\right.$ ) for the two evaluation dates, at least by $15 \%$ during the $60 \mathrm{DAE}$ and $30 \%$ for $75 \mathrm{DAE}$ for plants with plenty of flowers and fruits. These results were consistent with other studies (Jonckheere et al., 2004; Kabba et al., 2009). Cotton plants have a specific growth behavior, with flowers and fruits in the plants at the same phenological stage. Therefore, underestimation of hemispherical photography LAI measurements may be common, because reproductive structures and leaves are grouped along the stems, with consequent increase of light transmittance. Some authors reported underestimation of the LAI value, not only for commercial crops, but also in forested areas (Simões et al., 2007; Miller et al., 2007; Khabba et al., 2009; Awal et al., 2010).

Regarding this essential fact, equipment calibration and the appropriate choice of data collection period, especially in annual crops such as cotton, are crucial. Simões et al. (2007) found that hemispherical photography LAI obtained by CI110 , in an olive plantation study, underestimated by 44 to $37 \%$ the value measured by destructive method, depending on the cultivar used in the analysis. Other authors have also had similar results, such as Juárez et al. (2009), with reductions from 24 and $50 \%$ in a study on tropical forest and pasture, respectively.

Such behavior can be attributed to the fact that the gap fraction method considers the foliage distribution as completely random, ignoring leaves and reproductive structures overlapped in dense cover and considering only the average image projection per unit of area on a plane normal to the zenith (Jonckheere et al., 2005; Gonsamo \& Pellikka, 2008; Glatthorn \& Beckschäfer, 2014).

At 60 DAE, LAI obtained by hemispherical photograph showed correlation of 0.75 with the destructive method, and 0.69 with the non-destructive method, as shown in Table 1. The observed regressions and correlation coefficients were (y $=3.218 \mathrm{x}+1.752)$ and $\mathrm{R}^{2}=0.56$ for the destructive method and $(y=4.061 x+1.457)$ and $R^{2}=0.48$ for the non-destructive.

Figure 2 shows relationships between cotton leaf area index (LAI) from hemispherical photograph and two other methods:

Table 1. Mean Absolute Error (MAE), Root Mean Square Error (RMSE) and Pearson's correlations between leaf area index determined by hemispherical photography $\left(\mathrm{LAI}_{\mathrm{HP}}\right)$ and from destructive $\left(\mathrm{LAI}_{\text {dest }}\right)$ and not-destructive $\left(\mathrm{LAI}_{\text {not-dest }}\right)$ methods, for irrigated cotton in the semiarid region of Brazil at 60 and 75 days after emergence (DAE)

\begin{tabular}{lccccccc}
\hline & \multicolumn{3}{c}{ 60 DAE } & & \multicolumn{3}{c}{ 75 DAE } \\
\cline { 2 - 4 } \cline { 7 - 9 } & Pearson & MAE & RMSE & & Pearson & MAE & RMSE \\
$\mathrm{LAI}_{\text {not_dest }} \times \mathrm{LAI}_{\mathrm{HP}}$ & 0.69 & 1.50 & 1.04 & & 0.90 & 2.76 & 0.91 \\
$\mathrm{LAI}_{\text {dest }} \mathrm{x} \mathrm{LAl}_{\mathrm{HP}}$ & 0.75 & 0.89 & 0.90 & & 0.82 & 1.99 & 0.80 \\
\hline
\end{tabular}
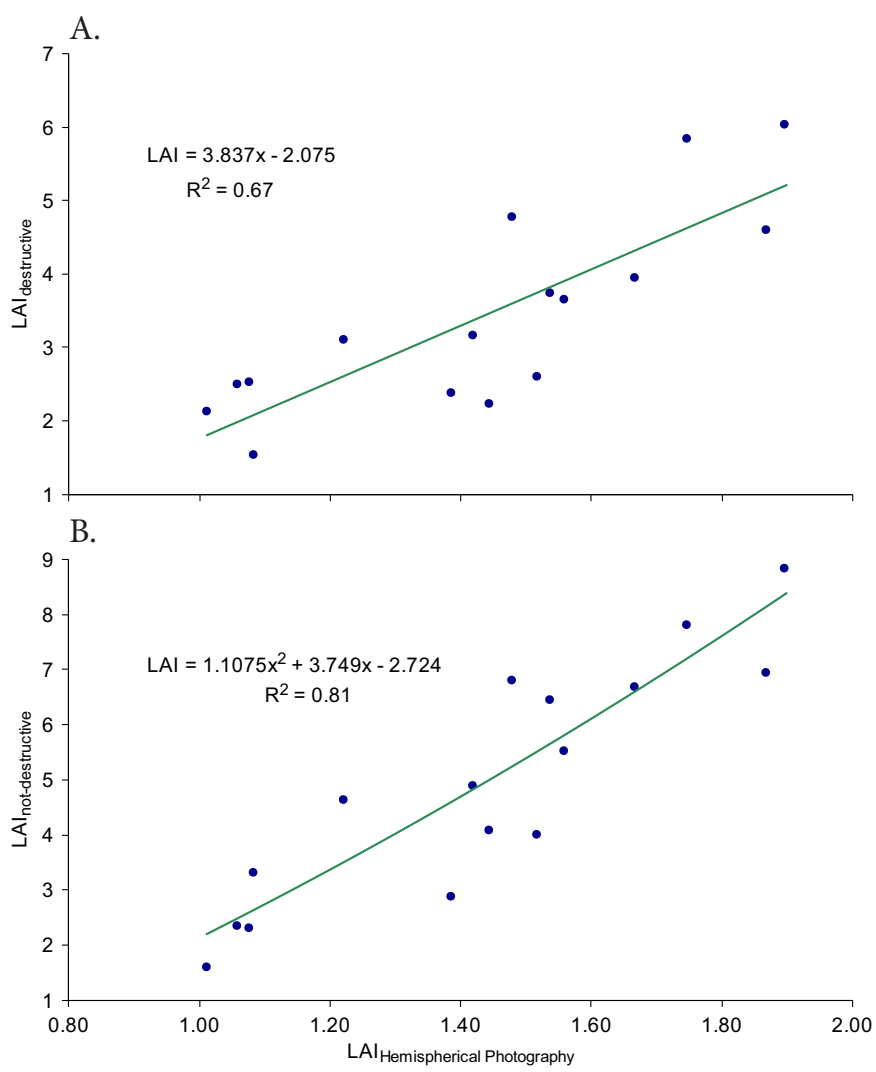

Figure 2. Regressions between leaf area index (LAI) obtained by hemispherical photography $\left(\mathrm{LAI}_{\mathrm{HP}}\right)$ and destructive method using LI-3100C (A) and the nondestructive method based on the midrib length of the leaves (B) for irrigated cotton using different doses of $\mathrm{N}$ and $\mathrm{P}$ at 75 days after emergence (DAE)

destructive method using LI-3100C and non-destructive method using the midrib length of the leaves, obtained during the second evaluation at 75 DAE for the different doses of $\mathrm{N}$ and $\mathrm{P}$.

High correlations between LAI from hemispherical photography and the other two methods, evaluated at 75 DAE (Figures $2 \mathrm{~A}$ and $2 \mathrm{~B}$ ), indicate that the measured LAI follow along with plant growth. Pearson's coefficient, presented in Table 1 for 60 and 75 DAE, increased from 0.75 to 0.82 and 0.69 to 0.90 for destructive and non-destructive methods, respectively. These relationships were highly significant $(\mathrm{p}<0.01)$ and were used to adjust LAI values determined using hemispherical photograph (Figure 2), allowing their future application for LAI evaluation in irrigated cotton in the semiarid region.

Considering that the destructive method is the one to provide the actual LAI with greater accuracy (MacFarlane et al., 2007; Jonckheere et al., 2004), it can be used as a reference for the correction of values obtained by hemispherical photography at 60 and $75 \mathrm{DAE}$. The mean absolute error (MAE) and the root mean square error (RMSE) of LAI estimated by hemispherical photography for the two evaluation dates are shown in Table 1 and may provide the magnitude of the error found, demonstrating that there was a better fit for the two data collection periods, between $\mathrm{LAI}_{\mathrm{HP}}$ and $\mathrm{LAI}_{\text {dest }}$, with lower values of MAE and RMSE indicating that $\mathrm{LAI}_{\text {dest }}$ is the best way to calibrate the $\mathrm{LAI}_{\mathrm{HP}}$.

Biomass determination is a reliable way to assess plant growth, nutrient availability and estimate productivity. 
Table 2. Regressions, determination coefficients and Pearson's correlations between the leaf area index measured by LI-3000C and by hemispherical photography and the yield and biomass (Biom), for irrigated cotton in the semiarid region of Brazil at 60 and 75 days after emergence (DAE)

\begin{tabular}{|c|c|c|c|c|c|c|c|c|}
\hline & \multicolumn{4}{|c|}{ Destructive method } & \multicolumn{4}{|c|}{ Hemispherical photography } \\
\hline & Var. & Regression & $\mathbf{R}^{2}$ & Pearson & Var. & Regression & $\mathbf{R}^{2}$ & Pearson \\
\hline \multirow{2}{*}{$60 \mathrm{DAE}$} & Yield & $-225.8 x^{2}+1532 x+865.1$ & 0.33 & 0.57 & Yield & $-4333 x^{2}+13296 x-6608$ & 0.80 & 0.89 \\
\hline & Biom & $1.091 x+1232$ & 0.76 & 0.87 & Biom & $4.792 x-2.212$ & 0.80 & 0.89 \\
\hline \multirow{2}{*}{75 DAE } & Yield & $-112.6 x^{2}+1213 x+185.3$ & 0.57 & 0.76 & Yield & $1734 x+348.1$ & 0.56 & 0.75 \\
\hline & Biom & $2.30 x+1.371$ & 0.85 & 0.92 & Biom & $9.740 x-4.713$ & 0.69 & 0.83 \\
\hline
\end{tabular}

The narrow relationship between LAI and plant biomass production led the study to estimate cotton biomass by $\mathrm{LAI}_{\mathrm{HP}}$ measurements in both evaluation periods, in order to understand the predictive ability of hemispherical photography as a means to reduce the hard work and high costs of the traditional methods of biomass measurement.

Regressions for biomass production in irrigated cotton plants were obtained as a function of leaf area index by hemispherical photography and by LI-3100C as shown in Table 2, for the two phenological stages studied. As expected, LAI followed the biomass increase during the two evaluations with correlations above $80 \%$ for both destructive and nondestructive methods, with highly significant relationships.

At $75 \mathrm{DAE}$, considered the phenological stage of cotton flowering, fruits were fully formed in the lower third of the plants at least in $70 \%$ of them, with some open bolls. During this stage, the dry fruit weight (DFW) significantly influenced the total biomass. It was observed that, in average, the dry fruit weight was two times higher than the sum of the dry weight of leaves, stems and branches. For comparison purposes, it is important to observe that, at $60 \mathrm{DAE}$, the DFW reached only $39 \%$ of the total above ground biomass. The $\mathrm{LAI}_{\mathrm{HP}}$ presented itself as a good estimator for cotton biomass even at $75 \mathrm{DAE}$, with cotton presenting many bolls (C1 stage) with Pearson's correlation coefficient of 0.92 (Table 2).

Relationships between cotton yield and $\mathrm{LAI}_{\mathrm{HP}}$ can be observed in Table 2 for the two evaluation dates. At 60 DAE, the $\mathrm{LAI}_{\mathrm{HP}}$ did not follow the yield increase for higher values, indicating downward trend after reaching the yield of 3591 $\mathrm{kg} \mathrm{ha}^{-1}$. On this date, the estimated yield was adjusted to a quadratic model with $\mathrm{R}^{2}$ of 0.80 .

At 75 DAE, cotton yield measured by $\mathrm{LAI}_{\mathrm{HP}}$ increased linearly in response to vegetation growth in this stage (Table $2)$, but showing a low correlation $\left(\mathrm{r}=0.75\right.$ and $\left.\mathrm{R}^{2}=0.56\right)$ with $\mathrm{LAI}_{\mathrm{HP}}$. Despite this, it is important to notice that, in this study, even when LAI was estimated by destructive method, previously considered as standard, cotton yield did not present good relationships with LAI for both evaluation periods. Crop yield is directly related to the quantity and quality of the vegetation, and LAI can be used as a good yield estimator, being obtained by hemispherical images and used to assess forests and others vegetated covers, such as perennial crops (Jonckheere et al., 2005; Simões et al., 2007; Zarate-Valdez et al., 2012). Considering that the CI-110 measures the light intercepted by the canopy, which directly influences LAI and biomass, this method has also been used not only for the estimation of crop yield, but also for nutritional assessment (Zarco-Tejada et al., 2005; Glatthorn \& Beckschäfer, 2014). Therefore, more research should be conducted in order to obtain adjustment and calibration to estimate cotton yield with accuracy using leaf area index by hemispherical photography.

\section{Conclusions}

1. Analysis of hemispherical images obtained using the Digital Plant Canopy Imager CI-110 is an appropriate method for estimating the leaf area index (LAI) in irrigated cotton, showing in this study, on average, Pearson's correlation coefficient equal to 0.785 , compared with the standard method.

2. The estimation of cotton biomass production is possible using hemispherical photographs with good accuracy, which is a suitable method for evaluating crop development.

3. LAI determined by hemispherical photography has potential for estimating cotton yield, but more studies must be conducted to attain good precision.

\section{Literature Cited}

Allen, R. G.; Pereira, L. S.; Raes, K.; Smith, M. Crop evapotranspiration: Guidelines for computing crop water requirements. Rome: FAO, 1998. 300p. FAO Irrigation and Drainage Paper, 56

Awal, M. A.; Ishak, W. I. W.; Bockari-Gevao, S. M. Determination of leaf area index for oil palm plantation using hemispherical photography technique. Pertanika Journal of Science \& Technology, v.18, p.2-32, 2010.

Carvalho, M. C. S.; Ferreira, G. B.; Carvalho, O. S.; Silva, O. R. R. F.; Medeiros, J. C. Nutrição, calagem e adubação. In: Beltrão, N. E. de M.; Azevedo, D. M. P. (eds). O agronegócio do algodão no Brasil. Brasília: Embrapa Informação Tecnológica, 2008. p.679-789.

Chianucci, F.; Cutini, A. Digital hemispherical photography for estimating forest canopy properties: Current controversies and opportunities. Forest Biogeosciences and Forestry, v.5, p.290-295, 2012. http://dx.doi.org/10.3832/ifor0775-005

Chirici, G.; Barbati, A.; Maselli, F. Modelling of Italian forest net primary productivity by the integration of remotely sensed and GIS data. Forest Ecology and Management, v.246, p.285-295, 2007. http://dx.doi.org/10.1016/j.foreco.2007.04.033

Clark, J.; Murphy, G. Estimating forest biomass components with hemispherical photography for Douglas-fir stands in northwest Oregon. Canadian Journal of Forest Research, v.41, p.1060-1074, 2011. http://dx.doi.org/10.1139/x11-013

Espinosa, M. L.; Acuña, E. C.; Espinosa, M. B.; Barrera, J. B. Commercial digital camera to estimate postharvest leaf area index in Vitis vinifera L. cv. cabernet sauvignon on a vertical trellis. Chilean Journal of Agricultural Research, v.70, p.315-322, 2010.

Fideles Filho, J.; Beltrão, N. E. de M.; Pereira, A. S. Desenvolvimento de uma régua para medidas de área foliar do algodoeiro. Revista Brasileira de Engenharia Agrícola e Ambiental, v.14, p.736-741, 2010. http://dx.doi.org/10.1590/S1415-43662010000700008 
Glatthorn, J.; Beckschäfer, P. Standardizing the protocol for hemispherical photographs: Accuracy assessment of binarization algorithms. Plos ONE, v.9, p.1-19, 2014. http://dx.doi.org/10.1371/ journal.pone.0111924

Gonsamo, A.; Pellikka, P. Methodology comparison for slope correction in canopy leaf area index estimation using hemispherical photography. Forest Ecology and Management, v.256, p.749-759, 2008. http://dx.doi.org/10.1016/j.foreco.2008.05.032

Jonckheere, I.; Fleck, S.; Nackaerts, K.; Muys, B.; Coppin, P.; Weiss, M.; Baret, F. Review of methods for in situ leaf area index determination. Part I. Theories, sensors and hemispherical photography. Agricultural and Forest Meteorology, v.121, p.19-35, 2004. http://dx.doi.org/10.1016/j.agrformet.2003.08.027

Jonckheere, I. G.; Muys, B.; Coppin, P. R. Derivative analysis for in situ high dynamic range hemispherical photography and its application in forest stands. IEEE Geoscience and Remote Sensing Letters, v.2, p.296-300, 2005. http://dx.doi.org/10.1109/ LGRS.2005.846904

Juaréz, R. I. N.; Rocha, H. R.; Figueira, A. M. S.; Goulden, M. L.; Miller, S. D. An improved estimate of leaf área index based on the histogram analysis of hemispherical photographs. Agricultural and Forest Meteorology, v.149, p.920-928, 2009. http://dx.doi. org/10.1016/j.agrformet.2008.11.012

Khabba, S.; Duchemin, B.; Hadria, R.; Er-Raki, S.; Ezzahar, A.; Chehbouni, A.; Lahrouni, A.; Hanich, L. Evaluation of digital hemispherical photography and plant canopy analyzer for measuring vegetation area index of orange orchards. Journal of Agronomy, v.8, p.62-72, 2009. http://dx.doi.org/10.3923/ ja.2009.67.72

Macfarlane, C.; Hoffman, M.; Eamus, D.; Kerp, N.; Higginson, S.; Mcmurtrie, R.; Adams, M. A. Estimation of leaf area index in eucalypt forest using digital photography. Agriculture Forest and Meteorology, v.143, p.176-188, 2007. http://dx.doi.org/10.1016/j. agrformet.2006.10.013
Marur, C. J.; Ruano, O. A reference system for determination of cotton plant development. Revista de Oleaginosas e Fibrosas, v.5, p.313-317, 2001.

Miller, S. D.; Goulden, M. L.; Rocha, H. R. The effect of canopy gaps on subcanopy ventilation and scalar fluxes in a tropical forest. Agricultural and Forest Meteorology, v.142, p.25-24, 2007. http:// dx.doi.org/10.1016/j.agrformet.2006.10.008

Simões, M. P.; Pinto-Cruz, C.; Belo, A. F.; Ferreira, L. F.; Neves, J. P.; Castro, M. C. Utilização de fotografia hemisférica na determinação do índice de área foliar de oliveiras jovens (Oleaeuro paea L.). Revista de Ciências Agrárias, v.30, p.527-534, 2007.

Woodgate, W.; Jones, D. S.; Suarez, L.; Hill, J. M.; Armston, D. J.; Wilkes, P.; Soto-Berelov, M.; Haywood, A.; Mellor, A. Understanding the variability in ground-based methods for retrievingcanopy openness, gap fraction, and leaf area index in diverse forest systems. Agricultural and Forest Meteorology, v.205, p.83-95, 2015. http://dx.doi.org/10.1016/j.agrformet.2015.02.012

Zarate-Valdez, J. L.; Whiting, M. L.; Lampinen, B. D.; Metcalf, S.; Ustin, S. L.; Brown, P. H. Prediction of leaf area index in almonds by vegetation indexes. Computers and Electronics in Agriculture, v.85, p.24-32, 2012. http://dx.doi.org/10.1016/j. compag.2012.03.009

Zarco-Tejada, P. J.; Ustin, S. L.; Whiting, M. L. Temporal and spatial relationships between within-field yield variability in cotton and high-spatial hyperspectral remote sensing imagery. Agronomy Journal, v.97, p.641-653, 2005. http://dx.doi.org/10.2134/ agronj2003.0257

Zhao, F.; Strahler, A. H.; Schaaf, C. L.; Yao, T.; Yang, X.; Wang, Z.; Schull, M. A.; Román, M. O.; Woodcock, C. E.; Olofsson, P.; NiMeister, W.; Jupp, D. L. B.; Lovell, J. L.; Culvenor, D. S.; Newnham, G. J. Measuring gap fraction, element clumping index and LAI in Sierra Forest stands using a full-waveform ground-based lidar. Remote Sensing of Environment, v.125, p.73-79, 2012. http:// dx.doi.org/10.1016/j.rse.2012.07.007 